\title{
МЕТАБОЛІЗМ ЦИСТЕЇНУ ПРИ ЕКСПЕРИМЕНТАЛЬНОМУ ГІПЕР- ТА ГІПОТИРЕОЗІ В ЩУРІВ
}

Вступ. Сірковмісні амінокислоти забезпечують процеси життєдіяльності клітин, підтримують цілісність їх редокс-потенціалу, знешкоджують вільні радикали та токсичні агенти, забезпечують процеси метилування і транссульфування. Відомо, що цистеїн утворюється в клітинах з гомоцистеїну, а використовуватися може, залежно від потреб клітини, на синтез білка, глутатіону, в десульфуразному шляху з утворенням гідроген сульфріду. Регуляція метаболізму сірковмісних амінокислот здійснюється на різних рівнях, у тому числі й ендокринною системою, зокрема тиреоїдними гормонами.

Мета дослідження - в експерименті вивчити вплив фрункціонального стану щитоподібної залози на активність ензимів циклу обміну цистеїну в тканинах печінки, нирок, мозку, міокарда, встановити вміст цистеїну, відновленого глутатіону та гідроген сульфріду в крові.

Методи дослідження. У роботі використано 40 щурів-самців масою 150-180 г. Для моделювання гіпер- і гіпотиреозу тваринам щоденно протягом 14-ти і 21-ї діб ентерально вводили розчин L-тироксину (200 мкг/добу на 1 кг маси) або мерказолілу (10 мг/добу на 1 кг маси). У мозку щурів визначали десульфурразну активність ензимів цистатіонін- $\beta$-синтази і цистатіонін-у-ліази, в крові - вміст цистеїну, гомоцистеїну і гідроген сульфріду.

Результати й обговорення. Щурам вводили L-тироксин та мерказоліл для моделювання станів гіпер- та гіпотиреозу, які підтверджували за вмістом вільного трийодтироніну, вільного тироксину і тиреотропного гормону в крові. В органах тварин з гіпотиреозом спостерігали зниження активності цистатіонін- $\beta$-синтази, цистатіонін-у-ліази і цистеїнамінотрансферази. Водночас введення L-тироксину призводило до підвищення активності даних ензимів у нирках та мозку. Гіпертиреоз супроводжувався зниженням, а гіпотиреоз не вплинув на концентрацію глутатіону в крові та на його вміст в органах тварин. Встановлено достовірне зниження концентрації гідроген сульсріду в крові при гіпотиреозі.

Висновок. Ураження серцево-судинної системи при гіпотиреозі може бути наслідком порушення процесів десульфурування в органах і тканинах, введення L-тироксину призводить до зниження синтезу глутатіону в сироватці та органах тварин, що може бути однією з причин розвитку оксидативного стресу в пацієнтів з гіпертиреозом.

КЛЮЧОВІ СЛОВА: тиреоїдні гормони; цикл десульфурування; цистеїн; глутатіон.

ВСТУП. Цистеїн - це сірковмісна амінокислота, що відіграє важливу біологічну роль в організмі людини: бере участь у фрормуванні вторинної структури білків, протеїновому фолдингу, посттрансляційних перетвореннях [1]. Він $€$ складовою глутатіону (GSH) та коензиму A. Співвідношення цистеїн/цистин та GSH/GSSG визначає редокс-потенціал у клітинах $[2,3]$. Вiдомо, що цистеїн бере участь у реакціях кон'югації ксенобіотиків та використовується для синтезу таурину.

Катаболізм цистеїну відбувається двома шляхами: синтез глутатіону й окиснення його тіольних груп. Перший шлях каталізує у-глута(c) В. М. Нечипорук, М. М. Корда, 2017. мілцистеїнлігаза (у-ГЦЛ, КФ 6.3.2.2), внаслідок чого синтезується у-глутамілцистеїн. У подальшій реакції синтезується глутатіон у результаті взаємодії у-глутамілцистеїну з гліцином. Відомо, що глутатіон $є$ потужним антиоксидантом, бере участь у процесах знешкодження ксенобіотиків, відіграє роль нейромодулятора та цитопротектора. Другий шлях утилізації цистеїну відбувається 3 участю цистеїндіоксигенази (ЦДО, КФ 1.13.11.20) з утворенням цистеїнсульсрінату [1]. Останній цистеїнсульфрінатдекарбоксилазою (ЦСД, КФ 4.1.1.29) перетворюється до гіпотаурину, який окиснюється до таурину. Частина цистеїнсульфрінату в реакції трансамінування 3 участю цистеїнсульфрінатамінотрансферази 
(ЦСАТ, КФ 2.6.1.75) перетворюється в $\beta$-сульфрінілпіруват, який розщеплюється до пірувату та сульсріту, що окиснюється до сульфратів сульфрітоксидазою (СО, КФ 1.8.3.1).

Десульфуразний шлях обміну цистеїну $\epsilon$ досить важливим, оскільки 3 ним асоціюється продукція сигнальної газової молекули гідроген сульсріду $\left(\mathrm{H}_{2} \mathrm{~S}\right)$ [4]. На сьогодні відомо, що $\mathrm{H}_{2} \mathrm{~S}$ відіграє велику роль у регуляції судинного тонусу та агрегації тромбоцитів, скоротливості міокарда, нейротрансмісії, секреції інсуліну, попереджує розвиток апоптозу клітин [5]. Метаболізм $\mathrm{H}_{2} \mathrm{~S}$ тісно пов'язаний з тіолдисульфрідним обміном та синтезом глутатіону [6].

Синтез $\mathrm{H}_{2} \mathrm{~S}$ із цистеїну каталізується кількома ензимами: цистеїнамінотранссреразою (ЦАТ, КФ 2.6.1.3), цистатіонін-ү-ліазою (ЦГЛ, КФ 4.4.1.1) цистатіонін- $\beta$-синтазою (ЦБС, КФ 4.2.1.22) [7-9]. Також $\mathrm{H}_{2} \mathrm{~S}$ може синтезуватись шляхом відновлення тіосульфату з участю тіосульсратдитіолсульсрідтранссерази (ТСТ, КФ 2.8.1.5) [10].

Гормони щитоподібної залози є регуляторами всіх видів обміну, в тому числі обміну амінокислот і білків. Проте вплив цих гормонів на метаболізм цистеїну все ще не зовсім зрозумілий. Недослідженими є питання впливу тиреоїдних гормонів на вміст гідроген сульсріду в організмі та фрункціональний стан ензимів, що забезпечують процеси обміну цистеїну і від фоннкціонування яких безпосередньо залежить концентрація $\mathrm{H}_{2} \mathrm{~S}$ у крові.

Мета дослідження - в експерименті дослідити вплив функціонального стану щитоподібної залози на активність ензимів обміну цистеїну в тканинах печінки, нирок, мозку, міокарда, встановити вміст цистеїну і відновленого глутатіону, рівні GSH та $\mathrm{H}_{2} \mathrm{~S}$ у крові при гіпер- і гіпотиреозі.

МЕТОДИ ДОСЛІДЖЕННЯ. Для досліджень використано 40 безпородних щурів-самців масою 150-180 г, яких утримували на стандартному раціоні. Усіх тварин поділили на 5 груп: 1-ша - контроль (інтактні щури, яким вводили інтрагастрально 1 \% розчин крохмалю); 2-га тварини, в яких викликали гіпертиреоз (щоденно протягом 14-ти діб вводили інтрагастрально L-тироксин на $1 \%$ розчині крохмалю по 200 мкг/добу на 1 кг маси); 3-тя - тварини, в яких викликали гіпертиреоз (щоденно протягом 21-ї доби вводили інтрагастрально L-тироксин на $1 \%$ розчині крохмалю по 200 мкг/добу на 1 кг маси); 4-та тварини, в яких викликали гіпотиреоз (щоденно протягом 14-ти діб вводили інтрагастрально мерказоліл на $1 \%$ розчині крохмалю по 10 мг/добу на 1 кг маси); 5-та - тварини, в яких викликали гіпотиреоз (щоденно протягом 21-ї доби вводили інтрагастрально мерказоліл на 1 \% розчині крох- малю по 10 мг/добу на 1 кг маси). На 14-ту і 21-шу доби щурів виводили 3 експерименту методом цервікальної дислокації. Для досліджень використовували плазму крові, тканину печінки та нирок. Дослідження проведено згідно із загальними етичними принципами експериментів на тваринах, ухваленими на Першому національному конгресі України з біоетики (Київ, 2001), Європейської конвенції про захист хребетних тварин, що використовуються для дослідних та інших наукових цілей (Страсбург, 1986), інших міжнародних угод і національного законодавства в цій галузі.

Печінку та нирки перфузували холодним 1,15 \% розчином калію хлориду і гомогенізували при 3000 об./хв у середовищі 1,15\% калію хлориду (співвідношення 1:3). Гомогенати центрифругували впродовж 30 хв при $1500 \mathrm{~g}$ і температурі $+4{ }^{\circ} \mathrm{C}$, отриману пост'ядерну фрракцію використовували для визначення активності ензимів, що забезпечують процеси обміну цистеїну в організмі: у-глутамілцистеїнлігази, цистеїндіоксигенази, сульфітоксидази, цистеїнамінотрансферази, цистатіонін-ү-ліази, цистатіонін- $\beta$-синтази, тіосульсратдитіолсульфідтрансферази.

Для інших досліджень міокард та мозок гомогенізували в середовищі 0,25 М сахарози, $0,01 \mathrm{M}$ Трис (pH 7,4) у співвідношенні 1:5 (маса/ об'єм) при 3000 об./хв (тесрлон-скло), центрифругували 30 хв при $600 \mathrm{~g}$ і температурі $4-6{ }^{\circ} \mathrm{C}$, отриману пост'ядерну фрракцію використовували для визначення активності ензимів, що забезпечують процеси обміну цистеїну в організмі: $у$-ГЦЛ та СО в міокарді й мозку, ЦДО і ЦБС у мозку, ЦАТ у міокарді.

Для визначення вмісту фрракцій глутатіону використовували безбілкові ТХО-екстракти печінки, нирок, мозку, міокарда. Для цього їх промивали холодним $1,15 \%$ розчином $\mathrm{KCl}$, подрібнювали ножицями, гомогенізували в $10 \%$ розчині трихлороцтової кислоти у співвідношенні 1:5 (маса/об'єм) при 3000 об./хв (тесрлон-скло). Супернатанти відбирали в мікропробірки Eppendorf i до проведення аналізу зберігали при температурі $-20^{\circ} \mathrm{C}$.

Рівень загального цистеїну визначали за реакцією з нінгідриновим реактивом у кислому середовищі після відновлення цистину в цистеїн [11]. Вміст GSH у тканинах органів визначали за реакцією з 5,5'-дитіобіс(2-нітробензойною)кислотою [12]. Вміст $\mathrm{H}_{2} \mathrm{~S}$ у сироватці крові визначали за реакцією утворення тіоніну з використанням N,N-диметил-п-френілендіаміну [13]. Активність $\mathrm{H}_{2} \mathrm{~S}$-утворювальних ензимів у пост'ядерному гомогенаті органів тварин оцінювали в адаптованих інкубаційних середовищах за при- 
ростом сульфрід-аніона, який визначали за реакцією утворення метиленового синього [14]. Активність ТСТ визначали в реакції відновлення тіосульфрат-аніона за утворенням сульфрід-аніона [14]. Активність у-ГЦЛ визначали за кількістю неорганічного фоссрату, що утворювався при гідролізі АТФ під час взаємодії глутамату із цистеїном [15]. Активність ЦдО визначали за швидкістю перетворення цистеїну в цистеїнсульфрінову кислоту [16]. Активність СО визначали за швидкістю окиснення сульфіт-аніона [17].

Для підтвердження станів гіпер- та гіпотиреозу в сироватці крові визначали вміст вільного тироксину $\left(\mathrm{BT}_{4}\right)$, вільного трийодтироніну $\left(\mathrm{BT}_{3}\right)$ та тиреотропного гормону (ТТГ) імуносрерментним методом з використанням наборів фрірми "Диагностические системы" (Російська Федерація) відповідно до інструкцій фірми-виробника.

Результати виражали як середнє \pm SEM 3 8 експериментів. Зміни p<0,05 розглядали як статистично достовірні. Статистичний аналіз проводили, використовуючи стандартні статистичні програми і t-критерій Стьюдента.

РЕЗУЛЬТАТИ Й ОБГОВОРЕННЯ. ЩОДЕННе введення тваринам по 200 мкг/кг L-тироксину протягом 14-ти і 21-ї діб викликало стан постійного гіпертиреозу, що підтверджувалося збільшенням у крові щурів 2-ї та 3-ї груп концентрації в $_{4}$ - відповідно, в 1,8 раза (3 $(11,07 \pm 0,47)$ до $(20,23 \pm 2,10)$ пмоль/л) і 2,4 раза $(3(11,07 \pm 0,47)$ до $(26,12 \pm 1,85)$ пмоль/л). При цьому концентрація ТТГ достовірно зменшувалась: на 14-ту добу-в 2,3 раза $(3(0,34 \pm 0,03)$ до $(0,15 \pm 0,02) \mathrm{MMO} / л)$, на 21-шу - в 4,25 раза (3 $(0,34 \pm 0,03)$ до $(0,08 \pm 0,01)$ мМО/л). Концентрація в $\mathrm{T}_{3}$ при введенні L-тироксину мала тільки тенденцію до зростання в обидва терміни експерименту, проте при статистичному аналізі зміни виявилися недостовірними.

Дляпригнічення продукції синтезу тиреоїдних гормонів використовували препарат "Мерказоліл" (1-метил-2-меркаптоімідазол), який блокує ензим пероксидазу, що бере участь у йодуванні тироніну в щитоподібній залозі до трийод- і тетрайодтироніну та знижує інкрецію тироксину. Введення тваринамщодняпо 10 мг/кг мерказолілу протягом 14-ти діб викликало зменшення вмісту вТ $_{4}$ у сироватці крові в 1,6 раза (3 $(11,07 \pm 0,47)$ до $(6,84 \pm 0,27)$ пмоль/л), застосування препарату протягом 21-ї доби призвело до зниження рівня вТ 4 майже в 3 рази $(3(11,07 \pm 0,47)$ до $(4,25 \pm 0,42)$ пмоль/л). Щоденне введення щурам по 10 мг/кг мерказолілу протягом 14-ти і 21-ї діб спричинило достовірне зростання рівня ТТГ в $1,6$ (з $(0,34 \pm 0,03)$ до $(0,54 \pm 0,05) \mathrm{mMO} / л)$ та 6,5 раза (з $(0,34 \pm 0,03)$ до $(2,21 \pm 0,16) \mathrm{mMO} / л)$. Водночас рівень вт 3 зменшився в сироватці крові в 3 рази на 14-ту добу $(3(2,58 \pm 0,24)$ до $(0,87 \pm 0,06)$ пмоль/л) і в 4 рази на 21-шу добу (3 $(2,58 \pm 0,24)$ до $(0,67 \pm 0,04)$ пмоль/л). Усі вищенаведені дані свідчать про те, що за допомогою L-тироксину було змодельовано стан, ідентичний до гіпертиреозу, а в щурів, яким вводили мерказоліл, розвивався виражений гіпотиреоз.

Дані, наведені на рисунку 1, свідчать про те, що введення тваринам мерказолілу викликало збільшення вмісту цистеїну в крові. Водночас застосування L-тироксину на рівень цистеїну в крові практично не впливало в обидва терміни дослідження. Наведені в таблиці 1 дані показують, що введення мерказолілу призводило до зростання рівня цистеїну в тканинах: у печінці на 28 і $44 \%$; у нирках - на 35 та $50 \%$; у серці на 33 і $60 \%$; у мозку - на 38 та 50 \%, відповідно, на 14-ту і 21-шу доби дослідження. Такі зміни можна пояснити посиленою утилізацією надлишкової кількості гомоцистеїну в шляху транссульфування, де цистеїн фрункціонує як проміжний метаболіт, що і призводить до підвищення концентрації останнього в крові та тканинах органів щурів, яким вводили мерказоліл [18].

Введення щурам мерказолілу призводило до достовірного зменшення $\mathrm{H}_{2} \mathrm{~S}$ у крові в 1,2 раза на 14-ту добу експерименту (з $(88,02 \pm 4,35)$ до $(72,9 \pm 3,50)$ мкмоль/л), а подальше введення протягом 21-ї доби спричиняло зниження концентрації $\mathrm{H}_{2} \mathrm{~S}$ в 1,3 раза (рис. 2).

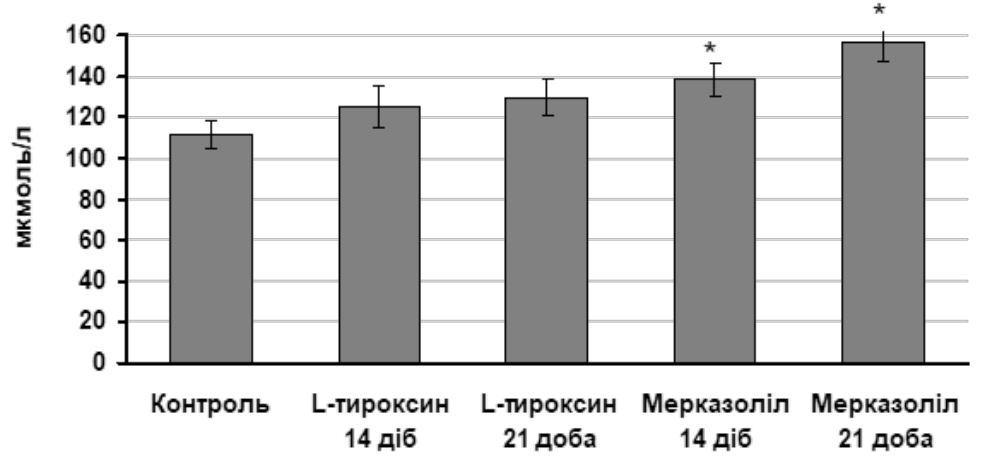

Рис. 1. Концентрація цистеїну (мкмоль/л) у сироватці крові щурів з моделлю гіпер- та гіпотиреозу.

Примітка. Тут, на рисунку 2, у таблицях 1-4: * - зміни достовірні відносно показників групи інтактних тварин. 


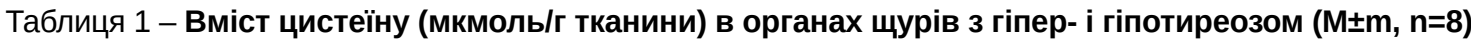

\begin{tabular}{|c|c|c|c|c|c|c|}
\hline \multirow{4}{*}{ Показник } & \multirow{4}{*}{$\begin{array}{c}\text { Об'єкт } \\
\text { дослідження }\end{array}$} & \multicolumn{5}{|c|}{ Група тварин } \\
\hline & & \multirow{3}{*}{ інтактні } & \multicolumn{2}{|c|}{ L-тироксин } & \multicolumn{2}{|c|}{ мерказоліл } \\
\hline & & & \multicolumn{4}{|c|}{ час від початку введення препаратів, доби } \\
\hline & & & 14 & 21 & 14 & 21 \\
\hline \multirow[t]{4}{*}{ Цистеїн } & Печінка & $0,25 \pm 0,01$ & $0,22 \pm 0,04$ & $0,19 \pm 0,05$ & $0,32 \pm 0,01^{*}$ & $0,36 \pm 0,02^{*}$ \\
\hline & Нирки & $0,94 \pm 0,07$ & $0,85 \pm 0,14$ & $0,70 \pm 0,10$ & $1,27 \pm 0,03^{*}$ & $1,42 \pm 0,02^{\star}$ \\
\hline & Серце & $0,15 \pm 0,01$ & $0,13 \pm 0,01$ & $0,12 \pm 0,02$ & $0,20 \pm 0,01^{*}$ & $0,24 \pm 0,02^{\star}$ \\
\hline & Мозок & $0,08 \pm 0,01$ & $0,07 \pm 0,02$ & $0,06 \pm 0,01$ & $0,11 \pm 0,01^{*}$ & $0,12 \pm 0,01^{*}$ \\
\hline
\end{tabular}

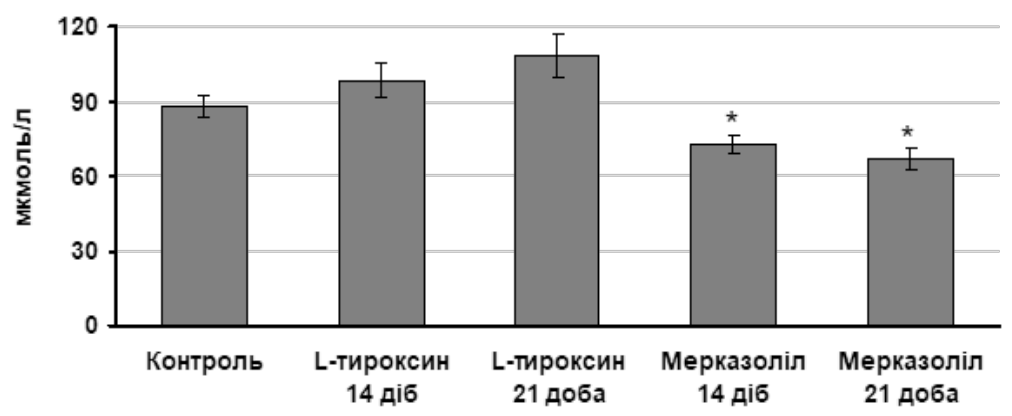

Рис. 2. Концентрація гідроген сульфіду (мкмоль/л) у сироватці крові щурів з моделлю гіпер- та гіпотиреозу.

Оскільки $\mathrm{H}_{2} \mathrm{~S}$, як і NO, має вазодилатаційні властивості й запобігає посиленому тромбоутворенню, то таке зменшення його вмісту при зниженій концентрації тиреоїдних гормонів має несприятливий ефект. Можливо, цей факт і пояснює розвиток ендотеліальної дисорункції і кардіоваскулярних розладів, які спостерігають у хворих з гіпотиреозом. Подібний результат отримали С. Hine та співавт. [19], які досліджували вплив тиреоїдних гормонів на продукування $\mathrm{H}_{2} \mathrm{~S}$ у печінці мишей. У тварин з гіпотиреозом було виявлено зниження активності цистатіонін-у-ліази і зменшення вмісту відповідної мРНК в гепатоцитах. L-тироксин підвищував рівень MPHK ЦГЛ залежно від дози і терміну введення. Автори зробили висновок, що тиреоїдні гормони стимулюють транскрипцію гена ЦГЛ, а також можуть діяти на посттранскрипційному рівні.
Ми також проаналізували вплив тиреоїдних гормонів на активність ЦБС, ЦГЛ і ЦАТ, що забезпечують десульфуразні реакції в організмі (табл. 2). У тканині печінки тварин з гіпотиреозом десульфуразна активність ЦБС та ЦГЛ достовірно знижувалася тільки на 21-шу добу (на 33 \%), а ЦАТ - і на 14-ту, і на 21-шу доби (відповідно, на 36 та 38 \%). Введення L-тироксину не призводило до змін активності цих ензимів у тканині печінки. У тканині нирок відбувалися подібні зміни. Так, активність ЦБС при експериментальному гіпотиреозі знижувалась на 18 та 28 \%, активність ЦГЛ - на 37 і 39 \%, активність ЦАТ зменшувалась лише при тривалому застосуванні мерказолілу - на 19 \%. Десульфуразна активність ЦБС та ЦГЛ у тканині мозку знижувалась при моделюванні тривалого експериментального гіпотиреозу на 33 і 45 \%. Активність

Таблиця 2 - Активність (нмоль/хв-мг білка) ензимів синтезу гідроген сульфіду в печінці, нирках, мозку і серці щурів з моделлю гіпер- та гіпотиреозу ( $\mathrm{M} \pm \mathrm{m}, \mathrm{n}=8)$

\begin{tabular}{|c|c|c|c|c|c|c|}
\hline \multirow{4}{*}{ Показник } & \multirow{4}{*}{$\begin{array}{c}\text { Об'єкт } \\
\text { дослідження }\end{array}$} & \multicolumn{5}{|c|}{ Група тварин } \\
\hline & & \multirow{3}{*}{ інтактні } & \multirow{2}{*}{\multicolumn{2}{|c|}{$\begin{array}{c}\text { модель гіпертиреозу } \\
\text { час від початку введення } \\
\text { L-тироксину, доби }\end{array}$}} & \multirow{2}{*}{\multicolumn{2}{|c|}{$\begin{array}{c}\text { модель гіпотиреозу } \\
\text { час від початку введення } \\
\text { мерказолілу, доби }\end{array}$}} \\
\hline & & & & & & \\
\hline & & & 14 & 21 & 14 & 21 \\
\hline \multirow[t]{3}{*}{ ЦБС } & Печінка & $4,04 \pm 0,34$ & $4,38 \pm 0,45$ & $4,65 \pm 0,37$ & $3,28 \pm 0,22$ & $2,72 \pm 0,27^{\star}$ \\
\hline & Нирки & $3,31 \pm 0,10$ & $3,33 \pm 0,22$ & $4,01 \pm 0,20^{\star}$ & $2,70 \pm 0,18^{\star}$ & $2,37 \pm 0,25^{\star}$ \\
\hline & Мозок & $0,35 \pm 0,02$ & $0,30 \pm 0,04$ & $0,56 \pm 0,06$ & $0,29 \pm 0,02$ & $0,23 \pm 0,02^{\star}$ \\
\hline \multirow{4}{*}{ ЦГЛ } & Печінка & $4,01 \pm 0,20$ & $4,17 \pm 0,23$ & $4,30 \pm 0,16$ & $3,06 \pm 0,31$ & $2,70 \pm 0,21^{\star}$ \\
\hline & Нирки & $0,92 \pm 0,04$ & $1,29 \pm 0,14$ & $1,84 \pm 0,15^{\star}$ & $0,58 \pm 0,03^{*}$ & $0,56 \pm 0,03^{\star}$ \\
\hline & Мозок & $0,20 \pm 0,01$ & $0,18 \pm 0,01$ & $0,24 \pm 0,04$ & $0,18 \pm 0,01$ & $0,11 \pm 0,02^{*}$ \\
\hline & Серце & $0,40 \pm 0,03$ & $0,52 \pm 0,02^{*}$ & $0,56 \pm 0,02^{*}$ & $0,28 \pm 0,02^{*}$ & $0,25 \pm 0,03^{\star}$ \\
\hline \multirow[t]{4}{*}{ ЦАТ } & Печінка & $1,67 \pm 0,12$ & $1,41 \pm 0,20$ & $1,80 \pm 0,29$ & $1,07 \pm 0,14^{\star}$ & $1,03 \pm 0,12^{*}$ \\
\hline & Нирки & $1,28 \pm 0,03$ & $1,44 \pm 0,08$ & $1,43 \pm 0,10$ & $1,20 \pm 0,10$ & $1,04 \pm 0,07^{*}$ \\
\hline & Мозок & $0,21 \pm 0,03$ & $0,34 \pm 0,03^{*}$ & $0,46 \pm 0,04^{\star}$ & $0,20 \pm 0,02$ & $0,14 \pm 0,01$ \\
\hline & Серце & $0,18 \pm 0,02$ & $0,13 \pm 0,01$ & $0,23 \pm 0,02$ & $0,14 \pm 0,02$ & $0,11 \pm 0,03$ \\
\hline
\end{tabular}


ЦАТ у тканині мозку зростала під впливом L-тироксину на 62 та $119 \%$. У серці тільки активність ЦГЛ зазнавала змін при моделюванні експериментального гіпер- та гіпотиреозу - при введенні L-тироксину вона підвищувалась на 30 і $40 \%$, водночас мерказоліл призводив до зниження активності даного ензиму на 30 та $38 \%$.

Глутатіон не лише відіграє важливу роль в інактивації активних фрорм кисню та підтримці тіол-дисульсрідного балансу, але і регулює функцію багатьох редокс-чутливих білків. 3 результатів, наведених у таблиці 3, випливає, що введення піддослідним тваринам L-тироксину чи мерказолілу не викликало суттєвих змін інтенсивності синтезу глутатіону із цистеїну в печінці, нирках та мозку. Водночас у щурів з гіпертиреозом процес суттєво зростав у тканині серця. Так, тривале введення гормону (протягом 21-ї доби) призводило до зростання активності у-ГЦЛ на $113 \%$. Як видно з таблиці 3, експериментальний гіпотиреоз не викликав достовірних змін концентрації відновленого глутатіону в крові. Водночас через 14 діб після введення L-тироксину його вміст зменшувався на $24 \%$, через 21 добу - на $34 \%$. Концентрація відновленого глутатіону в органах також достовірно знижувалася під впли- вом L-тироксину: в печінці - на 18 та $25 \%$; у нирках - на 20 і 27 \%; у серці - на 13 та $19 \%$; у мозку - на 15 і 21 \% порівняно $з$ контрольною групою тварин. М. Sajadian та співавт. [20] показали, що гіпертиреоз викликає зниження активності глутатіонпероксидази і призводить до розвитку оксидативного стресу в підшлунковій залозі щурів.

При вивченні цистеїнсульфрінатного шляху перетворення цистеїну було встановлено, що швидкість синтезу цистеїнсульфрінової кислоти в печінці щурів, яким вводили L-тироксин протягом 14-ти і 21-ї діб, мала тенденцію до зростання, проте при статистичному аналізі зміни виявилися недостовірними. Тільки моделювання тривалого гіпотиреозу протягом 21-ї доби викликало достовірне (на 43 \%) пригнічення першої реакції цистеїнсульфрінатного шляху в нирках експериментальних тварин. Також введення щурам мерказолілу протягом 21-ї доби призводило до пригнічення ЦДО в мозку на 29 \%. Отже, мерказоліл при його тривалому застосуванні (протягом 21-ї доби) спричиняє порушення метаболізму цистеїну до сульфатів за рахунок пригнічення першого ензиму цистеїнсульфрінатного шляху - ЦДО (табл. 4).

Таблиця 3 - Вміст відновленого глутатіону в органах (мкмоль/г тканини) та крові (мкмоль/л) щурів 3 гіпер- і гіпотиреозом

\begin{tabular}{|c|c|c|c|c|c|c|}
\hline \multirow{4}{*}{ Показник } & \multirow{4}{*}{$\begin{array}{c}\text { Об'єкт } \\
\text { дослідження }\end{array}$} & \multicolumn{5}{|c|}{ Група тварин } \\
\hline & & \multirow{3}{*}{ інтактні } & \multicolumn{2}{|c|}{ L-тироксин } & \multicolumn{2}{|c|}{ мерказоліл } \\
\hline & & & \multicolumn{4}{|c|}{ час від початку введення препаратів, доби } \\
\hline & & & 14 & 21 & 14 & 21 \\
\hline \multirow[t]{5}{*}{ GSH } & Кров & $58,5 \pm 4,31$ & $44,3 \pm 2,90$ * & $38,6 \pm 2,84^{*}$ & $60,4 \pm 4,80$ & $59,3 \pm 3,25$ \\
\hline & Печінка & $3,55 \pm 0,15$ & $2,91 \pm 0,11^{*}$ & $2,66 \pm 0,14^{*}$ & $3,05 \pm 0,25$ & $3,02 \pm 0,26$ \\
\hline & Нирки & $1,35 \pm 0,07$ & $1,08 \pm 0,05^{*}$ & $0,98 \pm 0,06^{\star}$ & $1,18 \pm 0,10$ & $1,12 \pm 0,09$ \\
\hline & Серце & $2,48 \pm 0,10$ & $2,15 \pm 0,05^{\star}$ & $2,01 \pm 0,10^{*}$ & $2,28 \pm 0,15$ & $2,22 \pm 0,16$ \\
\hline & Мозок & $2,20 \pm 0,09$ & $1,87 \pm 0,05^{\star}$ & $1,73 \pm 0,09^{*}$ & $2,07 \pm 0,16$ & $2,01 \pm 0,19$ \\
\hline
\end{tabular}

Таблиця 4 - Активність (нмоль/хв·мг білка) ензимів метаболізму цистеїну в печінці, нирках, мозку і серці щурів з моделлю гіпер- та гіпотиреозу (M士m, n=8)

\begin{tabular}{|c|c|c|c|c|c|c|}
\hline \multirow{4}{*}{ Показник } & \multirow{4}{*}{$\begin{array}{c}\text { Об'єкт } \\
\text { дослідження }\end{array}$} & \multicolumn{5}{|c|}{ Група тварин } \\
\hline & & \multirow{3}{*}{ інтактні } & \multirow{2}{*}{\multicolumn{2}{|c|}{$\begin{array}{c}\text { модель гіпертиреозу } \\
\text { час від початку введення } \\
\text { L-тироксину, доби }\end{array}$}} & \multirow{2}{*}{\multicolumn{2}{|c|}{$\begin{array}{c}\text { модель гіпотиреозу } \\
\text { час від початку введення } \\
\text { мерказолілу, доби }\end{array}$}} \\
\hline & & & & & & \\
\hline & & & 14 & 21 & 14 & 21 \\
\hline \multirow{3}{*}{ ЦДО } & Печінка & $1,12 \pm 0,13$ & $0,99 \pm 0,12$ & $1,44 \pm 0,15$ & $0,69 \pm 0,08$ & $0,66 \pm 0,07$ \\
\hline & Нирки & $0,42 \pm 0,03$ & $0,58 \pm 0,04$ & $0,85 \pm 0,07$ & $0,30 \pm 0,03$ & $0,24 \pm 0,03^{*}$ \\
\hline & Мозок & $3,83 \pm 0,31$ & $4,17 \pm 0,05$ & $4,94 \pm 0,06$ & $3,54 \pm 0,45$ & $2,72 \pm 0,20$ * \\
\hline \multirow[t]{4}{*}{ у-ГЦЛ } & Печінка & $4,50 \pm 0,86$ & $5,76 \pm 0,82$ & $9,65 \pm 1,93$ & $4,35 \pm 0,12$ & $7,30 \pm 0,88$ \\
\hline & Нирки & $2,66 \pm 0,58$ & $3,12 \pm 0,60$ & $5,90 \pm 0,56$ & $3,49 \pm 0,45$ & $4,75 \pm 0,45$ \\
\hline & Мозок & $1,46 \pm 0,71$ & $1,71 \pm 0,25$ & $1,64 \pm 0,32$ & $1,98 \pm 0,28$ & $2,68 \pm 0,59$ \\
\hline & Серце & $4,05 \pm 1,41$ & $4,46 \pm 0,63$ & $8,63 \pm 1,60^{*}$ & $4,49 \pm 2,38$ & $4,28 \pm 1,95$ \\
\hline \multirow[t]{2}{*}{ TCT } & Печінка & $1,18 \pm 0,13$ & $1,27 \pm 0,18$ & $1,50 \pm 0,22$ & $1,17 \pm 0,05$ & $1,11 \pm 0,25$ \\
\hline & Нирки & $0,84 \pm 0,08$ & $0,74 \pm 0,07$ & $0,89 \pm 0,09$ & $0,90 \pm 0,08$ & $0,57 \pm 0,04^{*}$ \\
\hline \multirow[t]{4}{*}{$\mathrm{CO}$} & Печінка & $3,77 \pm 0,30$ & $4,12 \pm 0,45$ & $4,33 \pm 0,31$ & $3,19 \pm 0,31$ & $3,11 \pm 0,42$ \\
\hline & Нирки & $3,67 \pm 0,29$ & $3,96 \pm 0,22$ & $4,19 \pm 0,27$ & $2,51 \pm 0,13^{*}$ & $2,22 \pm 0,10^{*}$ \\
\hline & Мозок & $0,91 \pm 0,22$ & $2,20 \pm 0,58^{*}$ & $2,38 \pm 0,19 *$ & $0,52 \pm 0,06$ & $0,56 \pm 0,05^{*}$ \\
\hline & Серце & $1,99 \pm 0,24$ & $1,83 \pm 0,20$ & $2,12 \pm 0,31$ & $1,35 \pm 0,16^{*}$ & $0,97 \pm 0,24^{*}$ \\
\hline
\end{tabular}


Подібні результати отримали J. Rakoczy та співавт. [21], які показали, що експресія МРНК ЦДО в плаценті мишей у третьому триместрі вагітності здійснюється 3 участю тиреоїдних гормонів. Автори вважають, що механізм такого впливу тиреоїдних гормонів на обмін цистеїну в організмі мишей відіграє важливу роль у синтезі сульсратів і таурину.

Тіосульфратдитіолсульфрідтрансфрераза (тіосульфратсульфруртрансфераза) - ензим, що каталізує взаємне перетворення тіосульсрату і гідроген сульфіду. 3 даних, наведених у таблиці 4, видно, що в печінці щурів, яким вводили L-тироксин та мерказоліл, активність цього ензиму достовірно не змінювалась, порівняно 3 інтактними тваринами, в обидва терміни дослідження. У нирках щурів активність тіосульфратсульфруртрансферази змінювалась тільки під впливом мерказолілу (при тривалому введенні активність знизилась на $32 \%$ ).

Активність кінцевого ензиму цистеїнсульсрінатного шляху - CO, що перетворює неорганічні сульфіти до сульфатів, у печінці практично не залежала від вираження і тривалості експериментального гіпер- та гіпотиреозу. В нирках при введенні мерказолілу спостерігали достовірне зниження активності цього ензиму в обидва терміни дослідження (на 32 та $40 \%$ ).

У мозку щурів, у яких моделювали гіпертиреоз протягом 14-ти діб, активність СО була на $142 \%$ вищою порівняно з інтактними тваринами, подальше введення препарату призвело до її зростання на $162 \%$. На відміну від L-тироксину, лише тривале введення мерказолілу спричинило

\section{СПИСОК ЛІТЕРАТУРИ}

1.Stipanuk M. H. Dealing with methionine/homocysteine sulfur: cysteine metabolism to taurine and inorganic sulfur / M. H. Stipanuk, I. Ueki // J. Inherit. Metab. Dis. - 2011. - 34 (1). - P. 17-32. doi: 10.1007/s10545009-9006-9.

2. Pajares M. A. Mammalian sulfur amino acid metabolism: a nexus between redox regulation, nutrition, epigenetics and detoxification / M. A. Pajares, D. PérezSala // Antioxid. Redox Signal. - 2017-30. doi: 10.1089/ ars.2017.7237.

3. S-sulfhydration as a cellular redox regulation / M. Iciek, D. Kowalczyk-Pachel, A. Bilska-Wilkosz [et al.] // Biosci Rep. - 2015 - 36 (2). pii: e00304. doi: 10.1042/ BSR20150147. зменшення швидкості утворення сульсратів із сульфрітів. На 21-шу добу експерименту активність ензиму в мозку знижувалася майже на 38 \% порівняно із щурами, яким препарат не вводили. Лише введення мерказолілу призводило до змін активності СО в серці тварин - вона достовірно зменшувалася на 32 та $51 \%$.

ВИСНОВКИ. 1. Нестача тиреоїдних гормонів в організмі супроводжується пригніченням десульфуразної активності трьох основних ферментів - цистатіонін-ß-синтази, цистатіонін-у-ліази і цистеїнамінотрансорерази та, як наслідок, зниженням концентрації $\mathrm{H}_{2} \mathrm{~S}$ у крові. Можливо, це $є$ одним із патогенетичних оракторів розвитку гіпертензії та гіперкоагуляції в пацієнтів з гіпотиреозом.

2. У всіх органах щурів з гіпертиреозом сповільнюється процес синтезу глутатіону.

3. Гіпотиреоз призводить до достовірного підвищення рівня цистеїну в сироватці крові, що $€$ результатом пригнічення цистеїнсульфрінатного шляху та реакцій десульфурування цистеїну.

4. Під впливом L-тироксину зазнає пригнічення процес синтезу глутатіону в органах тварин, що може бути однією з причин розвитку оксидативного стресу в пацієнтів з гіпертиреозом.

5. Подальші дослідження впливу тиреоїдних гормонів на різні аспекти метаболізму сірковмісних амінокислот дозволять покращити розуміння механізмів фрормування патологічних станів, що асоційовані з порушеннями їх синтезу, та оптимізувати підходи до їх фрармакотерапії. 
8. Paul B. D. $\mathrm{H}_{2} \mathrm{~S}$ : A novel gasotransmitter that signals by sulfhydration / B. D. Paul, S. H. Snyder // Trends in biochemical sciences. - 40, No. 11. - P. 687-700. DOI: 10.1016/j.tibs.2015.08.007.

9. Regulation of cystathionine gamma-lyase $/ \mathrm{H}_{2} \mathrm{~S}$ system and its pathological implication / K Zhao, H. Li, S. Li [et al.] // Front Biosci. (Landmark Ed). - 2014. 19. - P.1355-1369.

10. Thiosulfate: a readily accessible source of hydrogen sulfide in oxygen sensing / K. R. Olson, E. R. DeLeon, Y. Gao [et al.] // American Journal of Physiology. Regulatory, Integrative and Comparative Physiology. 2013. - 305, No. 6. - P. 592-603. DOI: 10.1152/ajpregu.00421.2012.

11. Gaitonde M. K. A spectrophotometric method for direct determination of cysteine in the presence of other naturally occuring amino acid / M. K. Gaitonde // Biochem. J. - 1967. - No. 104 (2). - P. 627-633.

12. Glutathione disulfide as an index of oxidative stress during postischemic reperfusion in isolated rat hearts / R. J. Verbunt, W. G. van Dockum, E. M. Bastiaanse [et al.] // Mol. Cell Biochem. - 1995 - 144 (1). P. 85-93.

13. Пат. України на корисну модель № $52136 \mathrm{U}$, МПК G01N 33/68. Спосіб визначення вмісту гідроген сульфріду в плазмі крові / Заічко Н. В., Пентюк Н. О., Мельник А. В. ; заявник і патентовласник НДІ реабілітації інвалідів Вінниц. нац. мед. ун-ту імені М. І. Пирогова. - № и 201003158 ; заявл. 19.03.10 ; опубл. 10.08.10, Бюл. № 15.

14. Пат. України на корисну модель № $45018 \mathrm{U}$, МПК G01N 33/00. Спосіб визначення продукції гідроген сульфріду в органах щурів / Заічко Н. В., Пен- тюк Н. О., Мельник А. В., Штатько О. І. ; заявник і патентовласник Науково-дослідний інститут реабілітації інвалідів (навчально-лікувальний комплекс) Вінниц. нац. мед. ун-ту імені М. І. Пирогова. № u 200904434 ; заявл. 05.05.09 ; опубл. 26.10.09, Бюл. № 20.

15. Orlowski M. Partial reaction by y-glutamylcysteine synthetase and evidence for an activated glutamate intermediate / M. Orlowski, A. Mrister // J. Biol. Chem. 1971. - 246, No. 23. - P. 7095-7105.

16. Catabolism of cyst(e)ine by rat renal cortical tubules / M. H. Stipanuk, J. De la Rosa, L. L. Hirschberger // J. Nutr. - 1990. - 120, No. 5. - P. 450-458.

17. Cohen H. J. Hepatic sulfite oxidase. Purification and properties / H. J. Cohen, I. Fridovich // J. Biol. Chem. 1971. - 246, No. 2. - P. 359-366.

18. Sulphur-containing amino acids exchange in cases of experimental hyper-and hypothyroidism in rats / V. Nechiporuk, N. Zaichko, M. Korda [et al.] // Georgian Medical News. - 10 (271). - P. 96-102.

19. Hypothalamic-pituitary axis regulates hydrogen sulfide production / C. Hine, H. J. Kim, Y. Zhu [et al.] // Cell Metabolism. 2017. - 25, No. 6. - P. 1320-1333. DOI: 10.1016/j.cmet.2017.05.003.

20 . The effect of experimental thyroid dysfunction on markers of oxidative stress in rat pancreas / M. Sajadian, M. Hashemi, S. Salimi [et al.] // Drug Development Research. - 2016. - 77, No. 4 -P. 199-205. DOI: 10.1002/ ddr.21312.

21. Placental and fetal cysteine dioxygenase gene expression in mouse gestation / J. Rakoczy, S. Lee, S. J. Weerasekera [et al.] // Placenta. - 2015. - 36, No. 8. -P. 956-959. DOI: 10.1016/j.placenta.2015.06.003.

\section{REFERENCES}

1. Stipanuk, M.H., \& Ueki, I. (2011) Dealing with methionine/homocysteine sulfur: cysteine metabolism to taurine and inorganic sulfur. J. Inherit. Metab. Dis., 34 (1), 17-32. doi: 10.1007/s10545-009-9006-9.

2. Pajares, M.A., \& Pérez-Sala, D. (2017). Mammalian sulfur amino acid metabolism: a nexus between redox regulation, nutrition, epigenetics and detoxification. Antioxid. Redox. Signal. doi: 10.1089/ars.2017.7237.

3. Iciek, M., Kowalczyk-Pachel, D., Bilska-Wilkosz, A., Kwiecień, I., Górny, M., \& Włodek, L. (2015). S-sulfhydration as a cellular redox regulation. Biosci. Rep., 36 (2). pii: e00304. doi: 10.1042/BSR20150147.

4. Powell, C.R., Dillon, K.M., \& Matson, J.B. (2017) A review of hydrogen sulfide $\left(\mathrm{H}_{2} \mathrm{~S}\right)$ donors: Chemistry and potential therapeutic applications. Biochem. Pharmacol. pii: S0006-2952(17)30695-0. doi: 10.1016/j. bcp.2017.11.014.

5. Chen, W., Guo, J.X., \& Chang, P. (2012). The effect of taurine on cholesterol metabolism. Mol. Nutr. Food. Res., 56 (5), 681-690. doi: 10.1002/mnfr.201100799.

6. Wang, R. (2010). Hydrogen sulfide: the third gasotransmitter in biology and medicine. Antioxid. Redox Signal, 12 (9), 1061-1064.
7. Kimura, H. (2011) Hydrogen sulfide: its production, release and functions. Amino Acids, 41 (1), 113-121. doi: 10.1007/s00726-010-0510-x.

8. Paul, B.D., \& Snyder, S.H. (2015) $\mathrm{H}_{2}$ S: A novel gasotransmitter that signals by sulfhydration. Trends in Biochemical Sciences, 40 (11), 687-700. DOI: 10.1016/j. tibs.2015.08.007.

9. Zhao, K., Li, H., Li, S., \& Yang, G. (2014) Regulation of cystathionine gamma-lyase/ $\mathrm{H}_{2} \mathrm{~S}$ system and its pathological implication. Front Biosci. (Landmark Ed), 19, 1355-1369.

10. Olson, K.R., DeLeon, E.R., Gao, Y., Hurley, K., Sadauskas, V., Batz, C., \& Stoy, G.F. (2013). Thiosulfate: a readily accessible source of hydrogen sulfide in oxygen sensing. American Journal of Physiology - Regulatory, Integrative and Comparative Physiology, 305 (6), 592603. DOI: 10.1152/ajpregu.00421.2012.

11. Gaitonde, M.K. (1967) A spectrophotometric method for direct determination of cysteine in the presence of other naturally occuring amino acid. Biochem. J., 104 (2), 627-633.

12. Verbunt, R.J., van Dockum, W.G., Bastiaanse, E.M., Egas J.M., \& van der Laarse, A. (1995) Glutathione 
disulfide as an index of oxidative stress during postischemic reperfusion in isolated rat hearts. Mol. Cell Biochem., 144 (1), 85-93.

13. Zaichko, N.V., Melnyk, A.V., \& Pentiuk, N.O. (2010). Sposib vyznachennia vmistu hidrohen sulfidu plazmy krovi [Method for determination of content of hydrogensulfide in blood serum]. Patent UA, No. 52136 [in Ukrainian].

14. Zaichko, N.V., Pentiuk, N.O., Melnyk, A.V., \& Shtatko, O.I. (2009). Sposib vyznachennia produktsii hidrohen sulfidu $v$ orhanakh shchuriv [Method for determination of production of hydrogen-sulfide in animal organs]. Patent UA, No. 45018 [in Ukrainian].

15. Orlowski, M., \& Mrister, A. (1971). Partial reaction by $\mathrm{y}$-glutamylcysteine synthetase and evidence for an activated glutamate intermediate. J. Biol. Chem., 246 (23), 7095-7105.

16. Stipanuk, M.H., De la Rosa J., Hirschberger L.L. (1990) Catabolism of cyst(e)ine by rat renal cortical tubules. J. Nutr., 120 (5), 450-458.

17. Cohen, H.J., \& Fridovich, I. (1971) Hepatic sulfite oxidase. Purification and properties. J. Biol. Chem., 246 (2), 359-366.
18. Nechiporuk, V., Zaichko, N., Korda, M., Melnyk, A., \& Koloshko, O. (2017). Sulphur-containing amino acids exchange in cases of experimental hyper- and hypothyroidism in rats. Georgian Medical News, 10 (271), 96-102.

19. Hine, C., Kim, H.J., Zhu, Y., Harputlugil, E., Longchamp, A., Matos, M.S., ... Ramadoss, P. (2017). Hypothalamic-pituitary axis regulates hydrogen sulfide production. Cell Metabolism, 25 (6), 1320-1333 DOI: 10.1016/j.cmet.2017.05.003.

20. Sajadian, M., Hashemi, M., Salimi, S., \& Nakhaee, A. (2016). The effect of experimental thyroid dysfunction on markers of oxidative stress in rat pancreas. Drug Development Research, 77 (4), 199-205. DOI: 10.1002/ddr.21312.

21. Rakoczy, J., Lee, S., Weerasekera, S.J., Simmons, D.G., \& Dawson, P.A. (2015). Placental and fetal cysteine dioxygenase gene expression in mouse gestation. Placenta, 36 (8), 956-959. DOI: 10.1016/j.placenta.2015.06.003.

\section{В. М. Нечипорук' ${ }^{1}$ М. М. Корда ВИННИЦКИЙ НАЦИОНАЛЬНЫЙ МЕДИЦИНСКИЙ УНИВЕРСИТЕТ ИМЕНИ Н. И. ПИРОГОВА ТЕРНОПОЛЬСКИЙ ГОСУДАРСТВЕННЫЙ МЕДИЦИНСКИЙ УНИВЕРСИТЕТ ИМЕНИ И. Я. ГОРБАЧЕВСКОГО}

\section{МЕТАБОЛИЗМ ЦИСТЕИНА ПРИ ЭКСПЕРИМЕНТАЛЬНОМ ГИПЕР- И ГИПОТИРЕОЗЕ У КРЫС}

\section{Резюме}

Вступление. Серосодержащие аминокислоты обеспечивают процессы жизнедеятельности клеток, поддерживают целостность их редокс-потенциала, обезвреживают свободные радикалы и токсические агенты, обеспечивают процессы метилирования и транссульфурирования. Известно, что цистеин образуется в клетках с гомоцистеина, а использоваться может, в зависимости от потребностей клетки, на синтез белка, глутатиона, в десульфуразном пути с образованием сероводорода. Регуляция метаболизма серосодержащих аминокислот осуществляется на разных уровнях, в том числе и эндокринной системой, в частности тиреоидными гормонами.

Цель исследования - в эксперименте изучить влияние фрункционального состояния щитовидной железы на активность энзимов цикла обмена цистеина в тканях печени, почек, мозга, миокарда, установить содержание цистеина, восстановленного глутатиона и сероводорода в крови.

Методы исследования. В работе использовано 40 крыс-самцов массой 150-180 г. Для моделирования гипер- и гипотиреоза животным ежедневно в течение 14-ти и 21-х суток энтерально вводили раствор L-mироксина (200 мкг/сутки на 1 кг массы) или мерказолила (10 мг/сутки на 1 кг массы). В мозге крыс

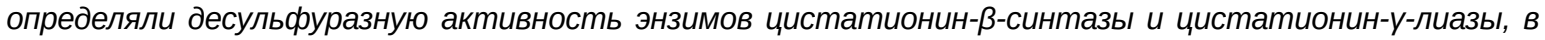
крови - содержание цистеина, гомоцистеина и сероводорода.

Результаты и обсуждение. Крысам вводили L-тироксин и мерказолил для моделирования состояний гипер- и гипотиреоза, которые подтверждали по содержанию свободного трийодтиронина, свободного тироксина и тиреотропного гормона в крови. В органах животных с гипотиреозом наблюдали снижение активности цистатионин- $\beta$-синтазы, цистатионин-у-лиазы и цистеинаминотрансферазы. В то же время введение L-тироксина приводило к повышению активности данных энзимов в почках и мозге. Гипертиреоз сопровождался снижением, а гипотиреоз не повлиял на концентрацию глутатиона в крови и на его содержание в органах животных. Установлено достоверное снижение концентрации сероводорода в крови при гипотиреозе. 
Вывод. Поражение сердечно-сосудистой системы при гипотиреозе может быть следствием нарушения процессов десульсрурирования в органах и тканях, введение L-тироксина приводит к снижению синтеза глутатиона в сыворотке и органах животных, что может быть одной из причин развития оксидативного стресса у пациентов с гипертиреозом.

КЛЮЧЕВЫЕ СЛОВА: тиреоидные гормоны; цикл десульфурирования; цистеин; глутатион.

\author{
V. M. Nechyporuk ${ }^{1}$, M. M. Korda ${ }^{2}$ \\ M. PYROHOV VINNYTSIA NATIONAL MEDICAL UNIVERSITY ${ }^{1}$ \\ I. HORBACHEVSKY TERNOPIL STATE MEDICAL UNIVERSITY2
}

\title{
METABOLISM OF CYSTEINE IN EXPERIMENTAL HYPER- AND HYPOTHYROIDISM IN RATS
}

\section{Summary}

Introduction. Sulfur-containing amino acids provide vital processes of the cell, maintain the integrity of the redox potential, neutralize free radicals and toxic agents that provide remethylation cycle and transsulfuration processes. It is known that cysteine is formed in cells from homocysteine, and can be used, depending on the needs of the cell for the synthesis of protein, glutathione, in a desulfuration pathway with the formation of hydrogen sulfide $\left(\mathrm{H}_{2} \mathrm{~S}\right)$. Regulation of the metabolism of sulfur-containing amino acids is carried out at different levels, including the endocrine system, in particular, thyroid hormones.

The aim of the study - to investigate experimentally the influence of thyroid gland functional state on the main enzymatic systems of the cysteine cycle in the tissues (liver, kidneys, brain, heart), concentration of cysteine and reduced glutathione and hydrogen sulfide in the blood.

Research Methods. 40 male rats weighing 150-180 g were used in the study. To model hyper-and hypothyroidism, animals were daily enterally administered with a solution of L-thyroxine (200 $\mu \mathrm{g} /$ day per $1 \mathrm{~kg}$ of weight) or mercazolil (10 mg / day per $1 \mathrm{~kg})$ for the 14th and 21st days. In the brain of animals, the desulfurase activity of cystathionine- $\beta$-synthase (CBS) and cystathionine-y-lyase (CGL) enzymes was determined, and cysteine, GC, and hydrogen sulfide content in the blood.

Results and Discussion. The rats were administered with L-thyroxine and mercazolil to simulate the states of hyper- and hypothyroidism, which were confirmed by the content of $f T_{3}, f T_{4}$ and TSH in the blood. In organs of animals with hypothyroidism, a decrease in the activity of CBS, CGL, and CAP was observed. At the same time, the introduction of L-thyroxin led to an increase in the activity of these enzymes in the kidney and brain. Hyperthyroidism was accompanied by a decrease, and hypothyroidism did not affect the concentration of glutathione in the blood and its content in the organs of animals. A significant decrease in the concentration of hydrogen sulfide in the blood with hypothyroidism was established.

Conclusion. The disorder of the cardiovascular system in hypothyroidism may be a consequence of the disoders of desulfuration processes in organs and tissues, the administration of L-thyroxin leads to a decrease in the synthesis of glutathione in the serum and animal organs may be one of the causes of the result formation of oxidative stress in patients with hyperthyroidism.

KEY WORDS: thyroid hormones; desulfuration cycle, cysteine, glutathione.

Отримано 12.10 .17

Адреса для листування: В. М. Нечипорук, Вінницький національний медичний університет імені М. І. Пирогова, вул. Пирогова, 56, Вінниця, 21018, Україна, e-mail: nechiporuk@vnmu.edu.ua. 